\title{
Mentor and Mentee Understanding of Character Building in Mentoring Activity at SMP Arrisalah
}

\author{
Weni Yulastri \\ STKIP PGRI SUMTERA BARAT \\ weniyulastri@yahoo.co.id
}

\begin{abstract}
Mentoring is one of an effective learning method in character building. Therefore, some improvements are much needed. One of them is improving mentor and mentees' understanding of the effectiveness of mentoring activity. The purpose of this research is to describe mentors and mentees' understanding about character building in mentoring activity at SMP ARRISALA, Padang. The result of the research shows that the mentors and mentees' understanding about character building in mentoring overall are good. However, to acquire good mentoring application, all mentors are hoped to make well mentoring plan which is relevant with the goals.
\end{abstract}

Keywords-noble character development; understanding of teachers and students; mentoring activities

\section{INTRODUCTION}

Nowadays, character building is one of an urgent problem for Indonesia, because of some phenomena that happened in society shows that a very serious character and moral crisis which can threaten the culture development and nation integrity in the future. Some character building activities are held in some schools and universities.

Character building in mentoring is one of the best alternatives to build the character and moral of the students or mente. In hence, mentoring whose some models can be applied effectively to develop the human resourch to support the organization competitively to face the progress and challange of globalization (Martoredjo, 2015)

SMP Arrisalah is one school that concern to build the character by mentoring activity, moreover mentorin acttivity is being a curriculum in Mulok which can be seen in the structure of SMP arrisalah Curriculum. There 10 characters of SMP Arrisalah students that must be obeyed such as 1) good faith ( Salimul Aqidah) 2) right devotion ( shahihul ibadah), 3) strong character ( matinul khuluq), 4) physical power ( qowiyyul jismi) 5) thinking briliantly ( mutsaqqoful fikri) 6) continence ( mujahadatun linafsi) 7) good time management ( harishun'ala waqtihi) 8,) well organized (munazhzhamun fi syu'unihi) 9)independent (qodirun'alal kasbi) 10) giving contribution (naafi'un loghoirihi). However, the activity of character building has not been done based on the aim and continuously. Furthermore, there are some problems which are faced while applying the 10 characters in SMP Arrisalah such as lack of cleanliness, lack of social environment awareness and bullying. This situation is very important to concern how the understanding of the mentor and mentee about the character building in mentoring activity that has been applied in SMP Arrisalah.

The successfulness of mentoring is very influential to some factors, nonetheless the biggest one is the mentor as ( Kreitner, 2005) emphasizes that mentoring is a method to acquire knowledge which then give some effects to the knowledge, attituden or the other skill of the students or mentee. Based on the Kitner's statement, mentor as facilitator must be able to make mentoring activity effective to reach the learning goals because mentoring makes the learning process faster. The mentor becomes a model, giving the feedback quickly, and identifying well practices. On the other hand, the subtantial competition of the mentor can be up- graded optimally because mentoring is an available human resource to master the knowledge, skills and attitudes which are related to the learning materials. Interpersonal relation is also well created because there is a positive interaction.

Furthermore, Kaswan (2012) explains mentoring is a partnership between mentor (who gives guidance) and mentees (who receive the guidance ). Since mentoring is an interpersonal relation in the form of awareness and support from those with experience and knowledge to those with lack of experience and knowledge. Therefore, mentoring reflects unique relations. No mentoring is exactly the same because the specific interaction happens differently from each other. In the unique relation, it comes partnership. Almost all of the mentoring relations involve mastering the knowledge. However, though mentoring is mutual but unbalanced relationship, the main goal is growing and developing mentees' character.

\section{METHODS}

This research was qualitative research. Principally. This method was going to give explanation, description critically or described phenomena or cases, a social interaction in society to search and found meaning in a context which had very real or natural setting and deep understanding, (Yusuf, 2003)

The informant of this research is tearchers and students. Teachers and students are in the location of research setting, SMP Arrisalah, Padang. Data were collected by using observation technique, deep interview, and documentation. Data were analyzed by using interactive analysis (Miles and Huberman). To validate the data, the 
researcher used the triangulation of sources. The result of this research describes how the mentor and mentees' understanding about the character building in mentoring activity analytically and objectively.

\section{FINDING AND DISCUSSION}

\section{Mentor/ Teacher and Mentee / Students' Understanding of Character Building in Mentoring Activity}

The result of the research done on (June $13^{\text {rd }}$ 2013-2017) is that not all of the mentors understood the application of mentoring activity well. The indicators of applying the mentoring activity can be seen from the input, process and output. The result the the researcher got from this research is as below

A. Indicators of Input. (Mentoring plan) which consists of the Completeness of the mentoring activities tools such as RKM ( Mentoring activity Planning) is not made and is not owned by the mentor. In mentoring activities, teachers should construct RKM which is relevant with the guide book used by the mentors. Based on the guide book, the RKM starts to establish the purpose, mind map, synopsis, narration, conclusion, evaluation, Philosophical value and game which is suitable with Islamic education guidance and which also supports some sources easy to be understood by the students. This planning should be implemented in RKM form which is more structured but it was not made by the mentors. Informant said that mentoring guide book is better enough to be a reference for applying the mentoring activity.

B. Indicators of application process of mentoring activities viewed from the sub indicators applied by the informant involve:

1. Effectiveness of character building in mentoring activity. The character building in mentoring activity can be considered effective. The process of mentoring engaged by the teachers consists of opening, material session, and closing. Each of them will be explained; (1) opening is opened by moderator, mentee or student of the mentoring. (2) reciting Qur'an (3) ziadah and murajaah (4) a seven minute lecture done by the students in turn. It aims at training the mentee to deliver character values through the stories as the model from the Prophet Muhammad SAW and deliver the successful person stories found in Modern Motivation books. (5) giving charity is done by closing the hand of the giver. This is one of the Islamic philosophy that giving something does not need any publication. In other words, keeping it hidden is to keep the good deeds. (5) reporting the daily worship as reciting Qur'an One day One juzz ( ODOJ), dhuha, qiyamullail, Almatsurah in Morning and afternoon, riyadoh/sports and house cleaning.

Material session. The Material session was given by giving a speech, question and answer, disscussion, and also psycology games. Kinds of the materials given include: aqidah, akhlak, sirah nabawiyah, tsaqofah islamiyah. While some skills include sewing, cooking, swimming, and out-bond.

Closing was given by telling qodhoya ( problem solving) which is related to personal, family, and human problem, and Rawa'i/ Good news by sharing the happiness to the other members in the mentoring group.

2. The effectiveness of Media and Learning sources which is relevant with the materials. The media used by the mentor in mentoring are Visual media, video of prophet stories. Learning sources used in mentoring are smart mentoring book produced by the team.

3. The proccess of the mentoring. The proccess of the mentoring was held by having some preparations, application and the closing. Rules used in the mentoring activities include 1) discipline of time, 2) timing of implementation of mentoring about 1,5 hour each meeting for 16 meetings. 3) the readiness of mentees such bringing Qur'an 4) note and 5) siting arrangement. Mentoring was held once a week, about the day and time based on the each group decision between mentor and mentee. In applying the mentoring activities the priority is the close relation between mentor and mentee. Close relation between mentor and mentee could be seen at arm in arm. It happened because of the mentor's commitment to do their role such as 1) when the mentor being the syech or someone who is very well in Islamic teaching who can make sutre the mentees 2) as the teacher or someone who forms their attitudes, role, 3) as parents or someone who has role as mom and dad to save and keep their children. 4) as a friend or a person to share problem, complaint, ask some money to buy something. In addition, it is forbidden to talk something useless inmentoring.

4. How are the process of collecting and proccessing the information for the result of the learning proccess

Collecting the information which relates with the learning attainment was done by doing an evaluation such as test and non test.

C. Output Indicators ( Evaluation and follow up)

1. The asssessment of learning result can be seen from some aspects : attitudes, knowledge, and skills. In attitudes aspect, not all of the students showed the good attitudes; some of them showed bad such as bullying their friend and not keeping the dorm clean. However, the good attitude from the mentee include; doing their test honestly, having the Islamic spirit in applying Islamic rules and caring with the Islamic world. For example, when the case in Genoside, Rohingnya, the mentee showed their empathy and also the participation in their payer, giving a big charity as mentees or students of Junior High School around 12 Millions. The implementation of the assessment or evaluation in mentoring activities for knowledge side and skills side consists of Mid-term Exam and Final Exam. Mid- term score prioritizes cognitive value through mentoring materials. On the other hand, the final exam prioritizes the score of Ibadah, Akhlak, and presence and every week the students make or fill the daily deeds for example, reciting Quran (ODOJ), dhuha, Qiyamul lail ( Tahadjud), Sunnah Rawatib, Almatsurah, Ribat, Ibadah, Akhlak ( sincerity, social Emphaty, good communication manners ) and presence 
2. Teacher Mentoring activity planning

Based on the result of the research, it was found that the mentors had not made RKM, when implementing the mentoring based on the guide book, smart mentoring guidance.arranged by composer team., The teachers are required to make mentoring schedule based on handbook that is adjusted with the mentoring participant condition.

3. Learning output follow-up viewed from some aspects: attitude, knowledge, and skill. It is required that the mentor should be a much hammered at mentoring participant's behavior in order not to bully their friends. The mentor also should explain about cleanness. It can be done by giving assignment to learners to make the material of seven minute lecture about the importance of cleanness in Islam and the negative impact in bullying close friend to the perpetrator bully and learners who bullying. In addition, mentoring material given strengthens the learner's knowledge about cleanness and Islamic brotherhood. Based on the findings, it was found that in forming attitudes, teachers work together with the discipline committee called (Komdis) under the student organization (Executive Board of Learners) that have function to monitor and build discipline. Komdis pays attention to discipline problems in the closing, as un steady hijab, cleaning affair, mainly in learning situation. The cases that are found include: the students stealing and lying. Punishment given for the type of infraction is warning Letter 1,2, and 3 . When checking the students are advised by the teacher. The minor violation includes, coming late and reaching the target of daily worship, like reciting Qur'an, tahfizd / memorizing Al-Qur'an, praying dhuha. Qiyamullail, regularly reading alma'tsurat, and giving punishment in memorizing al-qur'an. When the learners were on vacation, the control about the students' daily worship is done by their parent. The problems when the students who are out of parents' control include: watching television too long so that the students did not take aware of all of good characters that they have learned at schools and dormitories. Parental involvement to control the child does not fully run well. Evaluation sheet for achieving the target of worship was held by individual students and mentor. Then, those who did not reach the target were given remedy in mentoring. As a report for parents, a report form is given.

4. Follow-up of teacher's mentoring plan. The Follow-up on mentoring activities is less measurable. This has relevance to mentor planning that does not have an RKM, a global follow-up based on individual mentors.

Based on the findings of this study, generally the mentor, or teacher and the learners' understanding of good character formation in mentoring activities are in good category. Mentoring is understood as part of the curriculum that has been implemented by teachers and educators to build and curve good character of learners.

Fundamentally, the mentoring activity is one of the learning techniques centered on the students, under the mentor guidance. Each learner who is in the group interacts, discusses, debates and analyzes the mentoring material that has been planned before. The mentoring activity is an activity performed by a group of 8-12 people who are guided by a mentor who is conducted with a mutual counseling approach.

A mutual approach in mentoring aims at creating an atmosphere of mutual learning, mutual trust, and mutual experience and goodness that will provide a better change, that is forming a Muslim personality or akhlakul karimah embedded in teenagers' life.

In addition, mentoring is also a process to understand Islam, to be matured in knowledge based on the choice of competence, matured in addressing issues, matured in in making decisions, and matured in socializing recognizing the variety of human characters.

In mentoring, there is a focused group discussion that focuses in inter-human interactions, human aspects, and interpersonal relationships. Some of the keywords obtained from mentoring are as follows: (1) mentor, (2) mentoring activities starting from preparation, implementation, and evaluation (3) feedback.

Mentors conduct mentoring activities in accordance with the guidelines and objectives of the mentoring activities themselves. Nevertheless, the results of the study prove that mentoring activities have not fully run in accordance with the objectives.

Mentoring activity based on findings is the activity undertaken to be applied by learners in life. Implementation of mentoring activities was conducted in accordance with Albert Bandura's theory which states that mentoring is a mentoring activity based on the characteristics of learners in future. The mentoring activities that have been implemented can be seen in the scheme below: 


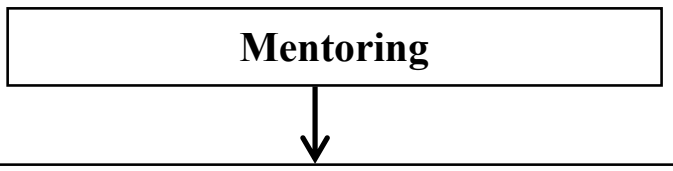

- Mentoring program is used to build make good characters of junior high school students Ar Risalah

- The goals are to make them independent, have self-regulated learning, learn outside of the classroom

\section{CONCEPT}

- The long life development (Erik) truths-kindness

- intellectual and ethical development stages (william) knowledge-environment

- theory of learning (Albert) learning is adapted based on how to learn a person (methods, strategies, media, etc.)

\section{Long life Development}

- The most relevant stage for middleage mentors

- Monitoring is a manifestation of adult secondary duty (Merriam)

- Main task of stagnant depends on the previous task development

- Strength of production and careness

- Need emotional maturity of guided people, self-identity and relationship skills

\section{Long life Development Intellectual and ethical development}

- The relationship of mentoring influenced by gradually intellectual and ethical ability

- Characterized by independence, flexibility, openness and ideal combination of support challenges

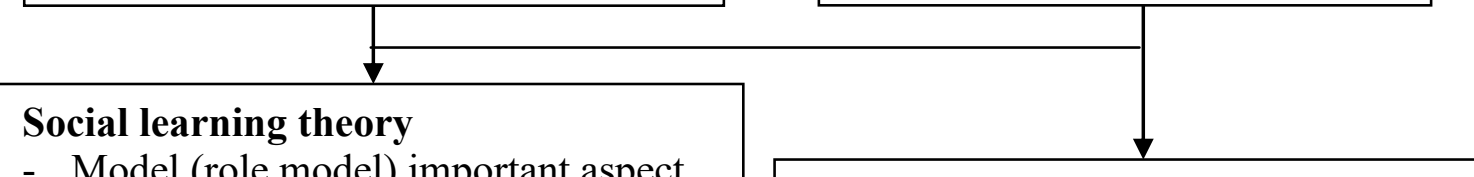

- Model (role model) important aspect in mentoring

he guided person will imitate the mentor's behavior, values and attitudes

he principles of reinforcement and imitation are related to behavioral control and modification

\section{Mentoring in education}

he program of mentoring is broadly used

hildrens program of moral formation, Amal yaumi, social values, etc

- The goals are to make independent, able to have self regulated learning, and learn out of the classroom

Based on observation and evaluation, it is found that mentoring program has not yet completely implemented . There are some reasons as follows:

a. It is only an independent learning 
b. it is an extracurricular activity

c. Educators or mentors did mentoring activity with a systematic planning

d. Mentors changed mentoring schedule based on their need

e. the need of infrastructure and the facilities

The impact of the problem is that mentoring activity did not completely affect positively on the students' development, mainly regarding with their behavior. Therefore, mentoring activity is required to implement systematically, completed with RKM, suitable media, and embed the concept of mentoring in any subjects. As the effect, the target of building good characters can be achieved maximally.

It was found that that bullying among students also influenced social values and the target of mentoring significantly. It was because of incondusively persuasive approach in building and changing the students' character. The impact of mentoring has not yet been reflected from the students' character. Moreover, when the students are located outside of school when they were school off and stayed home while spending their time watching tv.

Mentoring is human relationship based on a commitment between adults and youth, proposed to build students' characters and capabilities. The idea goes with Kaswan (2012) that defines mentoring as a partnership between mentor and mentee. Mentoring is interpersonal relationship in the form of awareness and support between those who have experience and knowledge with those who and knowledge. In mentoring, interpersonal relationship is unique. None of individuals has similar relationship, since the students have individual differences in special interaction. The unique relation includes learning partnership. More mentoring relationship involves acquiring knowledge, but the activity though the interaction was not balanced, the main target was for the mentees' growth and development.

\section{CONCLUSION}

The mentors and mentees' understanding in building noble characters was good enough generally. It was considered for curriculum that was implemented by teachers and educators to develop students' good characters. Therefore, mentors or teachers were expected to make the planning of mentoring activity, which is fixed with the mentoring goals, contents, and the activities are expected to be reflected in any other subjects. It should be implemented during the time schedule. Furthermore, the activities that should involve parents for controlling the students when they are school off.

\section{References}

Bandura, A. (1969). Principles of behavior modification. New York: Holt Rine hart \&Winston.

Erik H. Erikson. (1989). Identitas dan Siklus Hidup Manusia, Jakarta:Penerbit Gramedia.

Kaswan. (2012). Coaching dan Mentoring, Untuk Pengembangan SDM dan Peningkatan Kinerja Organisasi. Bandung: Alfabeta.

Kreitner, R. \& Kinicki, K.E. (2005). Organizational Behaviour. New York: McGraw Hill.

Mahmud, AAH (2011). Tarbiah Khuluqiah. Solo: Media Insani.

Miles, M B \& A. M. Huberman. (1992). Qualitative data analysis. Sage: publication, Inc.

Martoredjo. NT. (2015). Peran Dimensi Mentoring dalam Upaya Peningkatan Kualitas Sumber Daya Manusia. Humaniora 6 (4) Oktober 2015: 444-452

Yulastri, Weni, Rusmaladi, \& Harfina (1995). Penerapan Teknik mentoring dalam pengajaran Agama Islam untuk Pembentukan Ketaqwaan mahasiswa.Laporan penelitian.IKIP Padang.

Yusuf, A. Muri. (2003). Metodologi Penelitian. Padang: UNP Press 